\title{
PRESERVATION OF TANGIBLE AND INTANGIBLE CULTURAL HERITAGE: SAMPLE OF TURKISH BATH
}

\author{
Ayșem YANAR \\ Ankara Üniversitesi, Türkiye \\ ayanar@ankara.edu.tr \\ https://orcid.org/0000-0001-6240-6290 \\ Feryal SÖYLEMEZOĞLU \\ Ankara Üniversitesi, Türkiye \\ fsoylemezoglu@ankara.edu.tr \\ https://orcid.org/0000-0001-9874-4443 \\ Zeynep ERDOĞAN \\ Ankara Üniversitesi, Türkiye \\ zerdogan@ankara.edu.tr \\ https://orcid.org/0000-0002-1766-8301 \\ Özlen ÖZGEN \\ Atılım Üniversitesi, Türkiye \\ ozlen.ozgen@atilim.edu.tr \\ https://orcid.org/0000-0002-7629-9913
}

\begin{abstract}
Since the "Turkish bath" is an important symbol of a living and cultural wealth that has been passed down through generations, it is an important example in terms of preserving and maintaining both tangible and intangible cultural heritage together. The aim of the study is to reveal the spatial, functional, and traditional features of the Turkish bath in the concrete and intangible cultural context and to examine the objects of Turkish bath in detail. In the study, it was also aimed to evaluate the baths with historical value and converted into museums in the context of tangible cultural heritage. The method of his study is a descriptive survey model based on reviewing the literature on the cultural heritage and Turkish bath culture. The literature findings are supported with visual materials that highlight the characteristics of Turkish bath objects and reflect the Turkish bath museums, as well as the spatial, functional, and traditional properties of Turkish baths. In the conclusion section of the study, the importance of making efforts to keep the tradition of the Turkish bath alive and to maintain the functions of the historical baths located in almost every city of Anatolia where there is tangible and intangible cultural heritage are mentioned. In cases where this is not possible, it was emphasized that turning historical baths into museums and preventing their disappearance should be seen as a solution at least in terms of protecting the tangible cultural heritage.
\end{abstract}

Keywords: Cultural heritage, Turkish bath, Turkish bath tradition, Turkish bath objects, Turkish bath museums 


\title{
SOMUT VE SOMUT OLMAYAN KÜLTÜREL MIRASIN KORUNMASI: TÜRK HAMAMI ÖRNEĞİ
}

\begin{abstract}
ÖZ
“Türk hamamı” yaşayan ve kuşaklar boyu aktarılan bir kültürel zenginliğin önemli bir simgesi olduğundan hem somut hem de somut olmayan kültürel mirasın birlikte korunması ve sürdürülmesi açısından önemli bir örnektir. Bu çalışmanın amacı; somut ve somut olmayan kültürel mirasın birlikte korunması ve sürdürülmesi bağlamında Türk hamamının mekânsal, fonksiyonel ve geleneksel özelliklerinin ortaya konulması ve Türk hamamı objelerinin ayrıntılı olarak incelenmesidir. Çalışmada ayrıca, somut kültürel mirasın korunması bağlamında, tarihi değeri olan ve müzelere dönüştürülen hamamların da incelenmesi amaçlanmıştır. Çalışmanı yöntemi, kültürel mirasın korunması ve Türk hamam kültürü ile ilgili literatürün taranmasına dayanan betimsel tarama modelidir. Türk hamamının mekânsal, fonksiyonel ve geleneksel özelliklerinin yanı sıra Türk hamamı objelerinin özelliklerini vurgulayan ve Türk hamamı müzelerini yansıtan örnekler içeren görseller ile literatür bulguları desteklenmiştir. Çalışmanın sonuç bölümünde, Türk hamam geleneğinin yaşatılabilmesi, somut ve somut olmayan kültürel mirasın birlikte korunması açısından Anadolu'nun hemen her kentinde yer alan tarihi hamamların fonksiyonlarını sürdürülmesi için çaba gösterilmesinin önemine değinilmiş, bunun mümkün olmadığı durumlarda ise hamamların müzelere dönüştürülerek kaybolmalarının önlenmesinin en azından somut kültürel mirasın korunması açısından bir çözüm olarak görülmesi gerektiği vurgulanmıştır.
\end{abstract}

Anahtar Kelimeler: Kültürel miras, Türk hamamı, Hamam geleneği, Hamam objeleri, Türk Hamam müzeleri

\section{INTRODUCTION}

Bathhouses, history of which goes back to antiquity and which were first seen in ancient Greece around 300 B.C. were precedents of Roman baths in both spatial and functional properties. Romans planned bathhouses as places for health that also facilitated sports and entertainment and enabled their construction in many places. With the conquest of İstanbul, accumulations of Eastern Romans were transferred to the Ottomans and during the Ottoman Period, spatial and functional properties of Roman baths were revised and popularized throughout entire Anatolia (Kuruçay, 2011).

The definition of the word bath or bathhouse is; bathing, being hot and hot place. The definition shows similarity in Turkish, Arabic and Hebrew. However, the definition is not limited to these words. The word bath may be defined in a health context as "a place for washing up, cleansing, and healing", and in cultural and traditional context as "a place of health, social and cultural activities" (Ayçeman, 2016).

The word "bath" has gained a cultural meaning with the concept of Turkish baths. The values of Turkish baths from past to present; spatial, functional and traditional properties, show the importance of their conservation as part of cultural heritage. The conservation of Turkish baths as part of cultural heritage requires that the topics of conservation of both tangible and intangible heritages are handled together in a holistic approach.

Tangible cultural heritage may be explained with concepts of constancy and stability whereas it can be stated that intangible heritage changes and transforms with the people and contexts that keep it alive. Despite these differences, it is not possible to think about tangible cultural heritage separately from the people that constitute it and the events that surround it, nor is it possible to think about intangible cultural heritage separately from the tangible world in which it lives (Basat, 2013:61-62).

Research Article - This article was checked by iThenticate

Copyright $\odot$ The Turkish Online Journal of Design, Art and Communication 
In Yamato Declaration, it is stated that; the conservation of intangible cultural heritage is as important as the conservation of tangible cultural heritage and along with examples of countless intangible cultural heritage which are not attached to any place or object and with the properties of constancy, mutual benefit and enhancement, both tangible and intangible cultural heritage should be conserved together, holistically (UNESCO, 2004).

Ito (2003) points out the intensity of the relation between tangible and intangible cultural heritage and the impossibility of separating them and highlights that they should be handled in the contexts; "tangible cultural heritage materializes intangible cultural heritage" and "the role of intangible cultural heritage in facilitating tangible cultural heritage". Additionally, when structures, tools or products are not alongside living spaces or the people who produced them, they will lose their meaning, conserving only structures or objects will count as ignoring related living dynamics, which will lead to culture transforming into a nostalgic field instead of being conserved (Ito, 2003:2-4).

The bath culture, which reveals the relationship between human and space in the context of individual and social values, was affected by the changes in lifestyle after the modernization process, and modern people moved away from the traditional social order. However, in recent years, it has been observed that the traditional Turkish bath culture has come to the fore, and the studies emphasizing the richness of the origin of the Turkish bath culture have gained momentum. (Yegül, 2009). In their study, analyzing the Turkish bath culture in terms of cultural heritage, Özgen (2016) stated that a holistic conservation approach towards intangible cultural heritage adds life and dynamism to tangible cultural heritage, which can be characterized as silent structures from the past. Additionally, Özgen stated that special conservation of bathhouses, which are places with established historical pasts and are places still with life in them, carries a great importance in terms of transferring the Turkish bath culture and tradition to future generations (Özgen, 2016).

Baths have been one of the most interesting places in every era in terms of the relationship between human and location. Turkish baths, which have been irreplaceable parts of the Anatolian culture for thousands of years and have been declining in number, are especially important in terms of cultural heritage. A holistic method of conservation for both tangible and intangible cultural heritage may transform tangible cultural heritage from ancient, silent, lifeless structures or architectural elements into dynamic areas where lifestyles and living spaces are conserved and maintained together. The purpose of this study is the analysis of the spatial, functional and traditional properties of "Turkish Bath" based on literature and from the point of view of combined conservation of tangible and intangible heritage. In this work, it was also aimed to evaluate the baths with historical value and converted into museums in the context of tangible cultural heritage. The method of his study is a descriptive survey model based on reviewing the literature on the cultural heritage and Turkish bath culture. Moreover, the literature findings are supported with visual materials.

\section{SPATIAL PROPERTIES OF TURKISH BATHS}

There are both similarities and differences in the structures of Ottoman baths and Roman baths. Despite the three essential complementary elements for space organization, cold, warm and hot sections showed some locational differences, throughout the Middle Ages, they constituted the architectural structure of both Byzantine and Turkish baths. Another similarity that has not changed over the years is the heating system, namely, the furnace. Similar to Roman baths, Turkish baths in Anatolia are heated through a channel that passes under the flooring and continues through the walls. Water that is heated by the burning fire is poured into basins and this water used for bathing (Büyüktanır, 2009:17). These units are ranked in some studies as "warm (undressing) section, separation, cold section, hot section and furnace". Separation is the passage from the warm section to the cold section. This section is the most important property of the early bathhouses got smaller in time and was replaced by the cold section (Önge, 1988: 408; Yaman, 2010: 130,134).

Research Article - This article was checked by iThenticate 
There were no hot and cold-water pools in Ottoman baths. However, in hot spring baths there were cold and hot water pools as they were used for treatment purposes and, to make greater use of water. Another difference is that there usually is a pool with a water fountain in the middle of the warm section of Ottoman baths (Büyüktanır, 2009:17). Baths constituted a section of Ottoman social complexes that included mosques, madrasas, hospitals and hospices for public service which served different groups in the Ottoman society and it is seen that these baths had distinct plans and architectural styles that were constant through centuries. Architectural researches showed that bathhouses consisted of several units of square plan with domes which included directly accessible dressing rooms (cold section, undressing section or greenhouse), warm section, hot section that included private bathing sections called halvet and the furnace (Renda, 2012:369). An example of a Turkish bath with a square plan and dome is presented in Figure 1.

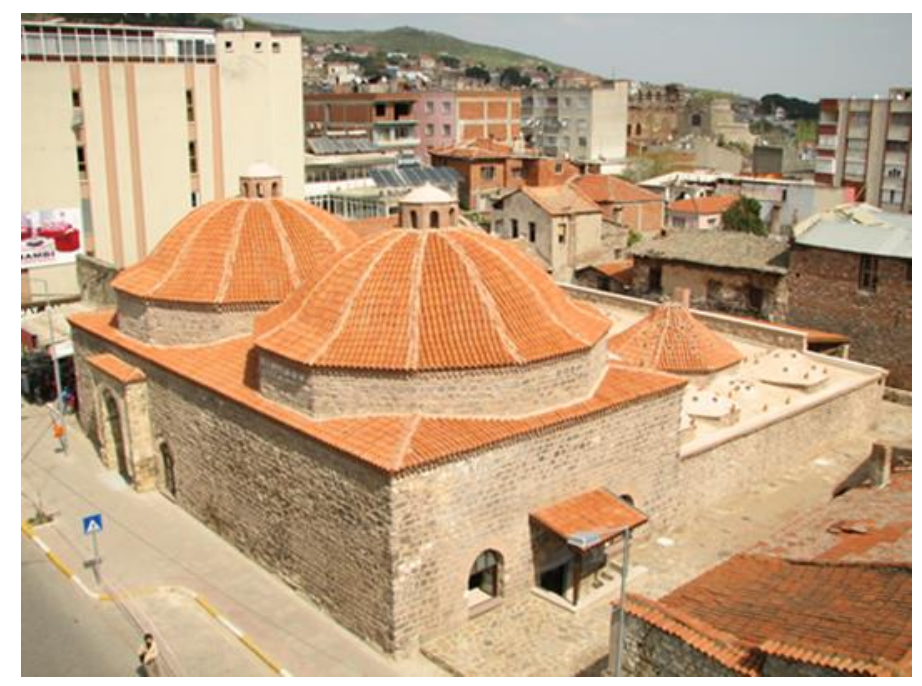

Figure 1. Example of a Turkish bath with a square plan and dome (Bergama Hac1 Hekim Bathhouse) (Anonymous, 2016)

Bergama was one of the most important cities of West Anatolia as it was the capital of the Pergamon Kingdom. It kept its importance during the Roman Period but came at a standstill during the Byzantine Period. It is an important place in Turkish bath architecture with its symmetrical plan and architectural features. The striking feature of Bergama Hacı Hekim Bath is the same plan is applied in equal dimensions and fully symmetrically in both parts. Its plain ornaments show that it is an important example of the 16th century Ottoman Turkish baths.

Research Article - This article was checked by iThenticate 


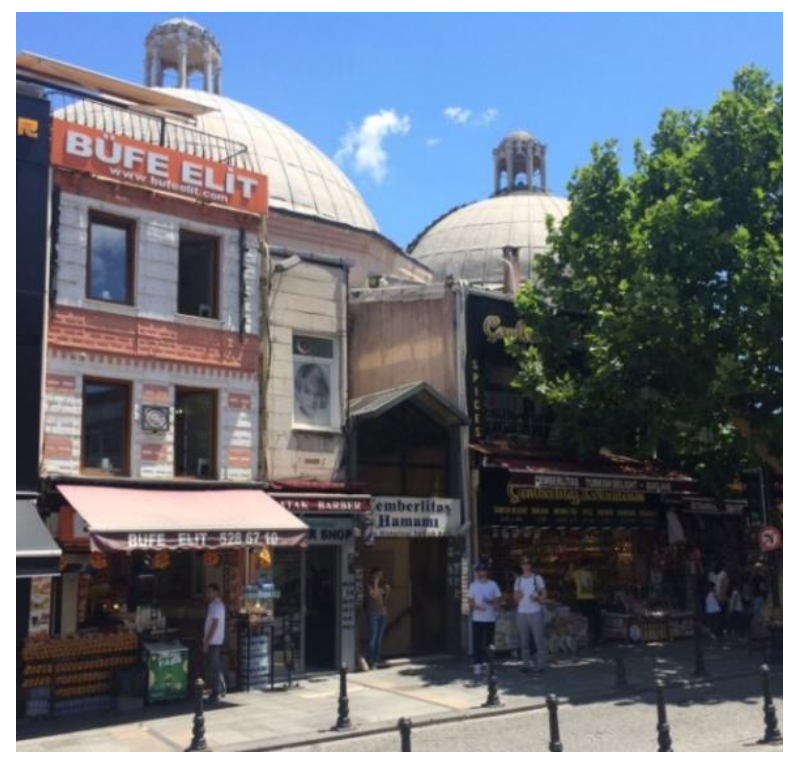

Figure 2. Çemberlitaş Bathhouse (Özgen's photo archive,2018)

The structural, functional and traditional features of Çemberlitaş Bath was determined that it tried to survive as a traditional Turkish Bath with a deep-rooted historical background. Çemberlitaş Bath is an aesthetic structure that responds to the domed silhouette of Atik Ali Pasha Mosque with its magnificent domes. This situation shows that Mimar Sinan was also a good city planner. However, Çemberlitaş Bath is now surrounded by additions serving as shops. The bath, which was used for disinfection purposes during the First World War, was used as a restaurant and carpet store until 1988 and continued to serve as a bathhouse as of 1988. "Çemberlitaş" is a bath that attracts the attention of foreign tourists mainly due to its historical and traditional nature.

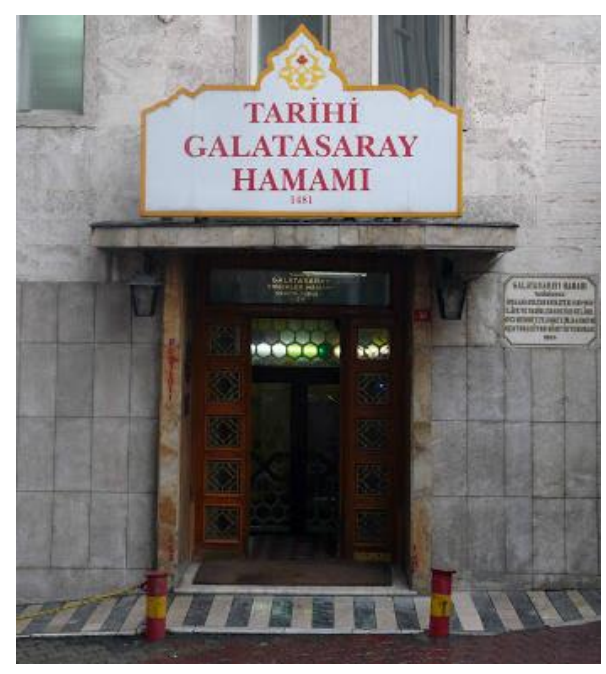

Figure 3. Galatasaray Bathhouse (Yanar's photo archive, 2017)

Galatasaray Bath is in the buildings of Galatasaray Mosque - (Kulliye), It was originally built, together with the kulliye itself during Beyazit II. Galatasaray Bath continues to maintain its importance day by day with its historical stance and attracts the attention of both domestic and foreign visitors. The

Research Article - This article was checked by iThenticate 
architectural features of the classical Turkish bath were used from the architecture of the bath, and it was restored in 1965.

\section{FUNCTIONAL PROPERTIES OF TURKISH BATHS}

Turkish baths can be analyzed in four groups in terms of their purposes, namely, public baths, private baths, hot springs and sea bathhouse. Public baths are defined as bathhouses with single or double function which can meet the bathing requirements of everyone (Figure 4). Turkish public baths are usually separated into two as single and double function baths. Single function baths serve to men in certain days of the week and serve to women in the remaining days, usually in low population regions or regions far away from cities. Double function baths are usually constructed in city centers for both men and women to use simultaneously. Double baths, which consist of separate sections for both men and women, have the door of the women's section opening to the side street for women to easily enter and exit. Bathhouses in the neighborhood that are only for women are called "avret" baths and the market bathhouses that are only for men are called "rical" baths (Bozok, 2005:70-71).

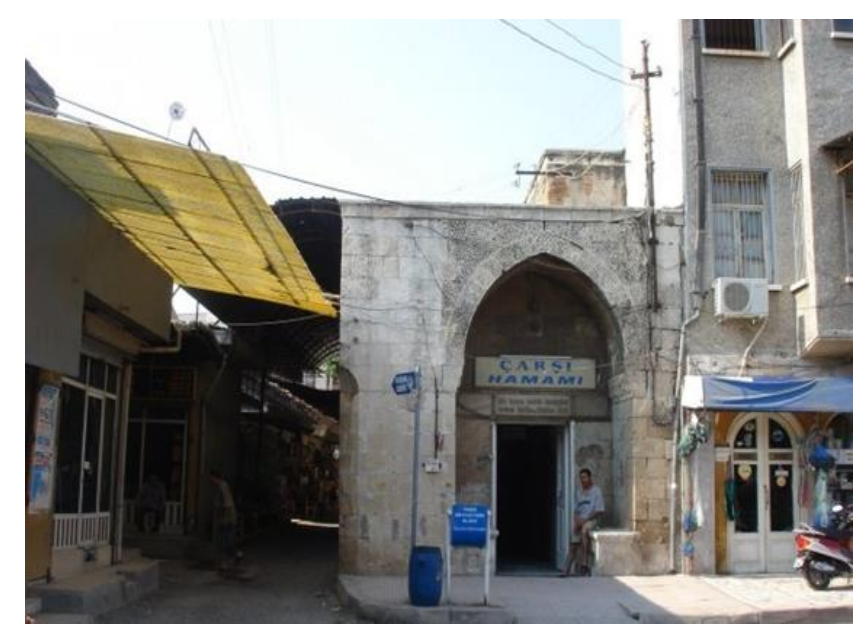

Figure 4. Public Bathhouse (Seyhan/Adana Market Bathhouse) (Anonymous, 2016a).

The Çarş1 Bath, located opposite the Great Clock Tower, was built by Pirî Pasha of the Ramazanoğulları in 1529. Adana Çarşı Bath attracts attention especially with its carved stonework on the entrance door.

Private baths are bathrooms in palaces, mansions and large houses. It is known that the bath is an important living space in this type of palace, mansion or large house owned by wealthy families.

Hot springs are bathhouses established on boiling, therapeutic, thermal groundwater sources. The history of utilizing hot water resources by constructing an architectural facility dates to very old times. Anatolia is a very rich geography in this sense. Many cities of Anatolia have hot, healing water resources (Figure 5).

Research Article - This article was checked by iThenticate 


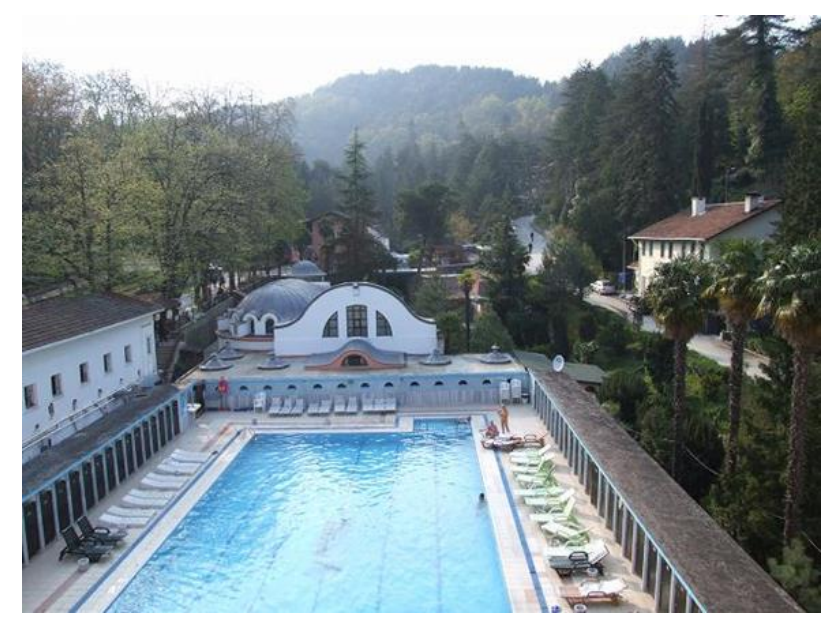

Figure 5. Hot Spring Bath (Yalova Thermal Spring) (Anonymous, 2016b).

Yalova Thermal Springs was formed 4000 years ago because of some natural events. It has become the place where people seek healing for more than 2000 years. During the Ottoman period, it was built by Sultan Abdülmecid (1831-1861). The fact that Bezm-i Alem Valide Sultan, mother of Sultan Abdülmecid, recovered from her rheumatism, made this place famous. Therefore, Sultan Abdülmecid built new bathrooms and mansions here. The fate of Yalova Thermal Springs changed with the arrival of the great leader Mustafa Kemal Atatürk in 1929. Atatürk made great efforts to make it a world-famous health center and water city. Today, Yalova Thermal Spring has a worldwide reputation thanks to Atatürk.

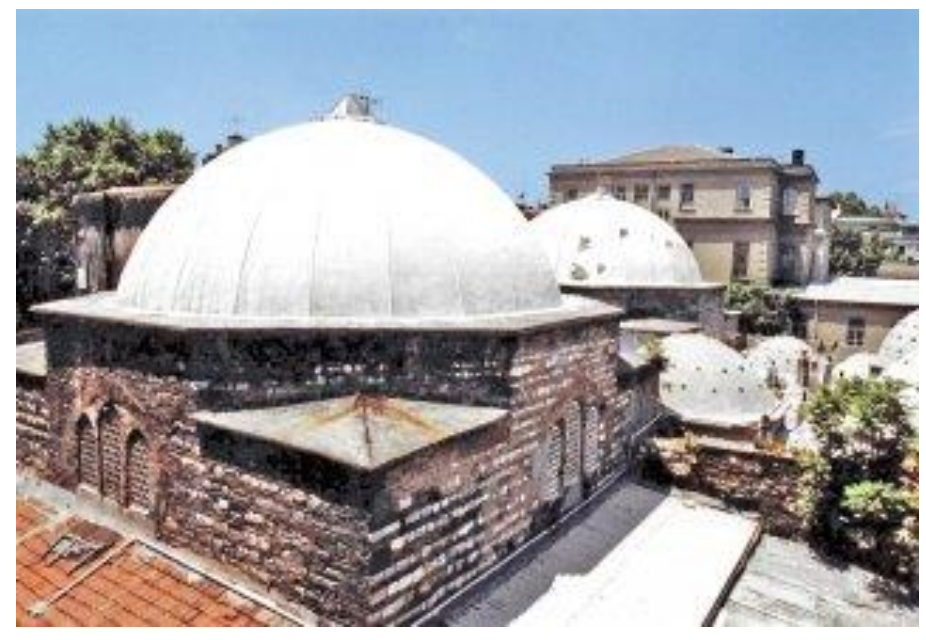

Figure 6. Cağaloğlu Bath (Anonymous, 2020).

The Cağaloğlu Bath was built by Sultan Mahmud I (1730-1754) to provide income for the library built and devoted to the Hagia Sophia Mosque. Different features from the classical ottoman architecture are seen in the arrangement of the cold section and hot section of the building because of Baroque style.

Apart from classical baths when Turkish baths are observed, the concept of sea bathhouse is encountered. Until the mid-19th century, men and boys in İstanbul went to swim in the sea wearing loincloths just as in hot baths to exercise and bathe. Sea bathhouses, with first examples seen in 19th century, are wooden structures constructed on stakes in the middle of the sea and connected to the shore with a pier (Figure 7). Additionally, there were private sea bathhouses constructed near Bosphorus

Research Article - This article was checked by iThenticate 
waterfront residences (Figure 8). Men were able to go swimming from the bathhouse and exit under the wooden curtain while women were able to swim in the designated section (Emiroğlu, 2010:14).

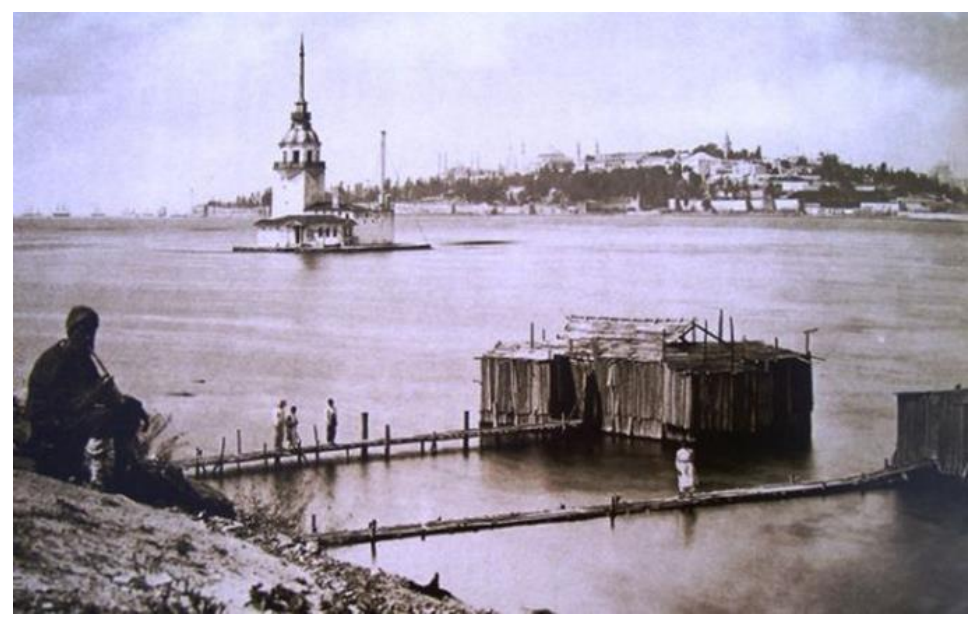

Figure 7. Sea Bathhouses in Ottoman Period (Üsküdar/İstanbul) (Anonymous, 2016c).

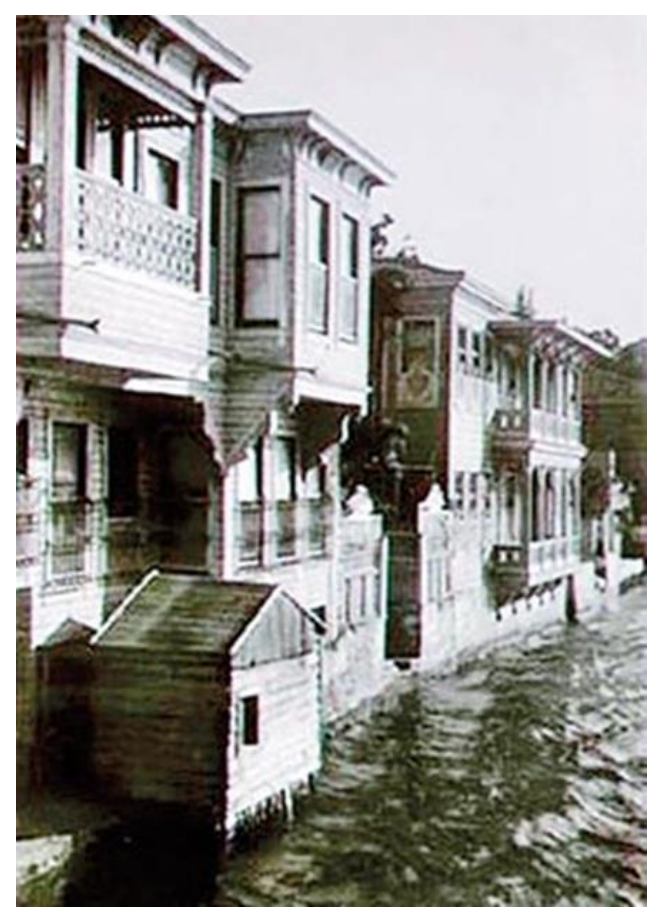

Figure 8. Private Sea Bathhouses in Ottoman Period (Bosphorus/İstanbul) (Anonymous, 2016c).

\section{TRADITIONAL PROPERTIES OF TURKISH BATHS}

The combination of the bathing culture brought by Turks from Central Asia and the water and bathhouse culture that has existed throughout Anatolia since antiquity, and the fact that cleanliness is one of the primary conditions of Islam are the bases for the development of Turkish bath culture. Since bath culture was a part of the social life with its cleaning and entertainment functions, it was very important in the Ottoman Empire (Renda, 2012:369). The bathing activity, a part of daily life in the Ottoman culture, was conducted in bathhouses in 10-15-day intervals. Bathhouses, which were constructed to meet the fundamental requirement of bathing also carried a ceremonial tradition in the Ottoman culture. "Bridal baths", "puerperal baths", "engagement baths", "soldier baths", "circumcision baths" are concepts which express this tradition (Y1lmazkaya, 2002:25-30). 
Baths had been irreplaceable parts of city life since antiquity. Primarily Greek, Roman and Turkish baths were distinguished as entertainment places and places where poetry, art and literature were discussed, in other words, public places (Türkan, 2009:163). During the Ottoman period, baths were accepted as places for socializing, communicating and entertainment, and were, for women, what coffeehouses which colored social lives for men were. The preparation to go to bathhouses, the journey and the entertainment at the bathhouse were all separate and meticulous social activities. It is theorized that going in the morning and staying at bathhouses all day was the result of this (Kuruçay, 2011; Renda, 2012: 380-381).

It is stated that women usually went to baths in groups of 10-20 women, with their children, servants and slaves, wore elegant clothes and jewelry for showing off to other women, socialized with other women by eating together and drinking coffee and sherbet together (Renda, 2012:382).

Lady Montagu, who described bathhouses she visited in the Ottoman cities she toured in detail in her letters. In one of them (1 May 1717), she wrote about some baths that have special meanings in terms of traditions. Lady Montagu was most influenced by bridal bath. She wrote that; bridal baths were carried out two days before the wedding, women from both the bride's and the groom's side were invited, nice foods were offered, and guests gave gifts to the bride-to-be who meticulously bathed and wore nice perfumes (Renda 2012). She wrote that young women escorted the bride to be through the three large sections of the bath by singing songs and after this tour, married women greeted the prospective bride with compliments and gave her gifts such as jewelry, handkerchiefs, etc. and the brideto-be thanked them by kissing their hands (Renda, 2012:383). These songs sang solo or in a choir in the bathhouse reminded Lady Montagu of the traditional bride songs arranged by Theocritus of Syracuse, one of the important poets of $3^{\text {rd }}$ century B.C. Yegül (2009:100) states that despite there are no direct connections between these bride songs called epithalamium in antiquity and the Turkish bath traditions, this similarity is still notable due to the fact that it reminds of the past of Anatolia that coalesces with its rich culture.

It is a common tradition for those coming out of the bath to wish each other "good health to you" in Turkish "sihhatler olsun". There is a consensus among the bathers that washing in the bathhouse is a source of healing. In this sense, body cleaning in the hammam is also a part of folk medicine (Davulcu, 2020:203).

\section{RICHNESS OF TURKISH BATH CULTURE}

\section{Turkish Bath Objects}

Objects used in Turkish baths reflect the richness of the Turkish bath culture. With the efforts of some collectors and bath museums opened in the recent years, this richness is tried to be transferred to future generations.

"Naim Arnas Collection" is a very important collection which brings the richness of Turkish bath culture to present. In the book published by Tofaş Sanat Galerisi (Tofaş Art Gallery) (2009) called "Eski Hamam, Eski Tas," a large chapter is dedicated to the Naim Arnas Collection. Among the primary Turkish bath objects in the Naim Arnas Collection are bathing bowls, pitchers, censers, rose water vessels, soap boxes-soaps, combs-comb pouches, mirrors, pattens-clogs, loincloths, towels and cheesecloths.

Research Article - This article was checked by iThenticate 


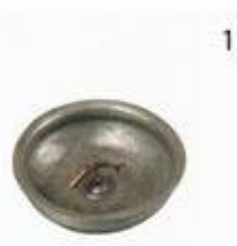

1

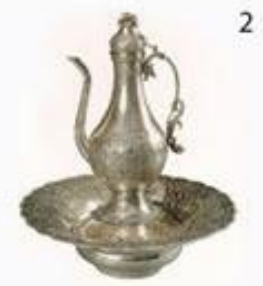

4
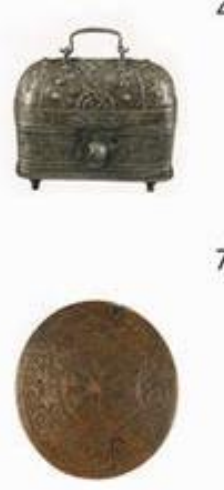

1. Bath Bowl
2. Pitcher
3. Incencory and Rose
Water Flesh
4. Soap Dish

5

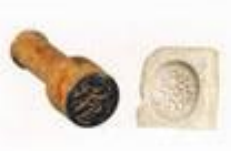

8

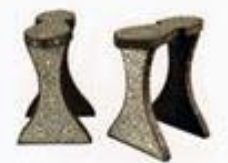

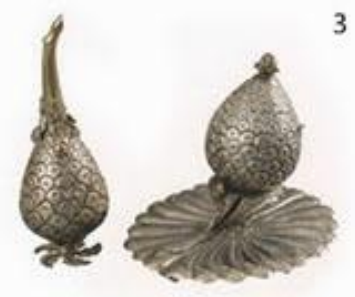

5. Soap and Seal

6. Comb and Comb Pauch

7. Mirror

8. Patten

9. Loincoth and Towel

Figure 9. Turkish bath objects (Naim Arnas Collection) (Tofaş Art Gallery, 2009: 127-323).

Bathing bowl, pitcher and basin, censer and rose water vessel, soap box, soap and seal, comb and comb pouch, mirror, patten, loincloth, towel, bath glove can be ranked as bath and cleaning tools (Arl1 1990). These tools and materials take place in Anatolian and Turkish bath culture.

Bathing bowl: It is a leading cleaning, carrying, bath tools. The ones made of copper, brass-yellow, bronze is available (Arl1 1990).

Pitcher and basin (pitcher set): Turkish pitcher and basins draw attention with their aesthetic features as well as being used as bathing bowls. There are ones made of metal, porcelain and glass. China and some European countries produced pitcher sets, which were very common in Ottomans as export goods and gifts, from metal and porcelain and sent to Turkey (Türkoğlu 1995). It is used in cleaning, carrying and baths. In addition to pitcher and basin (pitcher set) made of copper, brass-yellow, bronze, there are also museum works made with tombak technique.

Censer and rose water vessel: While cense is defined as the container in which odorous wood substances etc. burnt in religious ceremonies are put, rose water vessel is described as a pear-shaped little container with spout mouth used to sprinkle rose water (Anonymous 2019a). It was frequently used in houses and mosques during the Ottoman period (Türkoğlu 1995). Censer and rose water vessel originated from the tradition of ending meal with rose water and sweet-smelling (Erdoğdu 2000).

Soap Box: It is defined as a copper container with cover and bottom filter in which soap, pouch, comb is put (Anonymous 2019b). There are soap boxes made of brass-yellow (copper-zinc alloy).

Soap and Seal: Soaps are produced in different regions of Turkey with the names of bittım, laurel, green, olive oil. It is one of the tools used in Turkish Bath culture. Seal is an instrument, stamp, seal made of

Research Article - This article was checked by iThenticate 
metal, rubber, etc., in which a person's name or title is engraved to the contrary (Anonymous 2019c). Seals were used instead of signatures. In addition, workshop signs were found on potteries, mudbrick fragments, weaving loom weights. Terracotta, glass, obsidian, ivory, bone, horn, asphalt, wood and some metals were used for seal making (Arseven 1950a). They were also used on soaps.

Comb and Comb Pouch: It is defined as a tool including teeth used to separate hair and whisker and to hold hair. The combs used by the Turks were made of ivory, one short and two-sided and the other long. Short combs were generally used by women in the Turkish bath and are still used. Expressions such as good health to you or verses related to hair were written on ivory bath combs so that these writings were not removed into the water. These combs were produced in ranked shops at the street called Tarakcilar next to the Grand Bazaar in Istanbul and sent all over Turkey from here (Arseven 1952). Pouches are used for different purposes in daily life. It is produced as leather, fabric, knitting (Koçu 1969). The comb pouch is used for the purpose of keeping comb like other tools.

Mirror: It is a handicraft product made of glass. Its surrounding and handle can be decorated with the remains of marine animals (Arl1 1990). The old Turkish hand mirrors were firstly in wood and then in a metal frame. There are foursquare, round, egg-shaped ones. Some of them do not have handle. The back and edges of those made of wood are decorated with carved mother of pearl. The metal ones are silver, gold-plated or tombac. The metal plate covering the back of the mirror is generally decorated with relief decorations (Arseven 1958). There are different types of mirrors in Turkish daily life such as hand mirror, wall and console mirrors, tall dressing mirror, cushion mirror, reflecting mirror, street mirror. Silver, ivory, precious stones and jade mirrors are valuable examples (Anonymous 1997).

Patten: It is a shoe with a wood high foot and a leather collar used for wearing foot. It is worn in wet and muddy places such as baths and washroom. In the ornamented bathing pattents, the collar is covered with broadcloth. There are silver-plated, mother-of-pearl inlaid, collar embroidered ones (Arseven 1950b).

Loincloth: There are different bath loincloths for men and women. Men wear around the waist; women wrap around their armpits. The width of the women's bath loincloth is wider (Koçu 1969). Atalayer (1980) reports that the bath loincloth is weaved in $90-100 \mathrm{~cm}$ and wider as pink-white, yellow-white, black-white, blue-white colors.

Towel: It has the meanings of a thin towel, usually woven from cotton yarn; cotton or linen cloth, napkin in the form of large handkerchiefs used while eating and to dry hand (Anonymous 2019c). In the Ottoman cuisine, basins and bathing bowls were used to wash hands before and after meals, and towel for drying (Erdoğdu 2000). These are weavings with one or two looped sides obtained with warp yarns in addition to weft yarns. Besides hand towel, face towel, bath towels, they are woven as fabric (Ortaç, 1994). It absorbs water and is used in body drying.

Bath Glove: It was also called dirt pouch. While women and men bath gloves were white alpaca woven, bath attendant pouches were black alpaca woven (Kocu 1969). It is woven from silk, mohair, goat hair, synthetic fiber. It is a hand and machine loom weaving product that is still produced and used.

Many European painters were interested in the Turkish bath and painted it. The oil painting about women's bath by French painter Jean Jacques Francois Le Barbier (1738-1826) is presented in Figure 10. In this work, a magnificent, elegant and entertaining bath is depicted, and details and richness of bath objects are remarkable. 


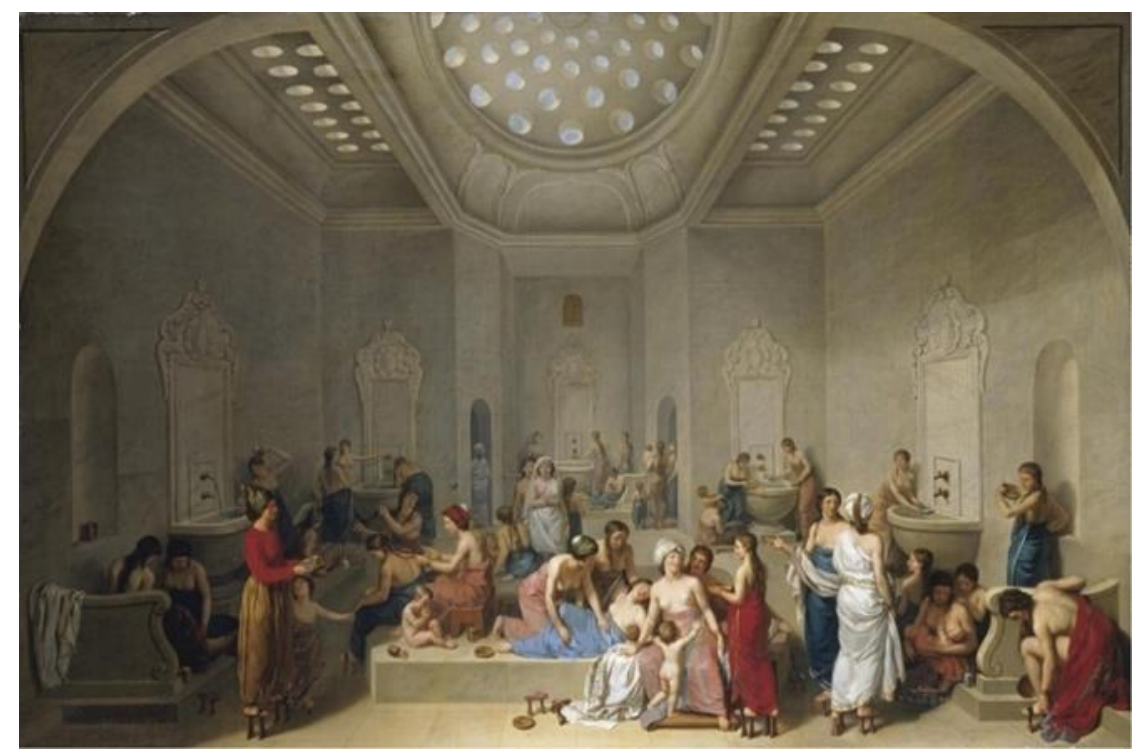

Figure 10. Turkish Women's Bath (J. J. F. le Barbier) (Anonymous, 2016d).

\section{Traditional Use of Turkish Bath Objects}

Kuruçay (2011) states that, following the Tanzimat Reform Era, bath tools and materials became ethnographical treasures, aesthetical properties of all objects, primarily, silk loincloths, ivory engraved combs, embroidered rag packs, lace decorated towels, copper bowls, rose water vessels, mother of pearl inlaid clogs and stamped soaps, came into prominence and depending on the materials of their production and the way of their exhibition, these objects became objects of competition for women which reflect their social and economic statuses. Objects used in bathhouses are grouped into two categories as the objects used by bathhouse employees for customers and the objects brought by customers for themselves. Provisions prepared for customers in bathhouses are bath related objects such as loincloths, clogs and towels as well as pleasure and offering provisions such as hookahs, coffee-tea sets and backgammon equipment. Objects brought along by clients vary for women and men. Sometimes baskets or wooden suitcases were used instead of rag packs. In rag packs of women, there were loincloths, pattens or clogs, threaded towels, bath bowls, soap boxes, scrub mitts, combs, hairclips, sequined, beaded or pearly cheesecloths, mirrors, silver jewelry boxes, mascara applicators, henna and mascara bowls, tweezers and blusher packs. Objects brought along by men and used in baths were very limited compared to those of women. Some of these objects were shaving razors, shaving brushes, soaps, mirrors, fragrances, scrub mitts and washcloths (Uluumay 2009:13-15).

In Turkish-Islamic baths, massage was replaced by scrubbing with gloves. Scrubbing was usually conducted on the nice, heated marble platform called "göbek taşı" which resided at the center of the domed and wide hot bathing room; however, it may be extremely hot for some people (Yegül, 2012:42).

\section{Turkish Bath Museums}

Since ancient times, baths have been one of the most important parts of urban life. It shows that the Turkish bath has a functional structure that serves a variety of purposes. Elmasoğlu and Ertürk (2019) stated that Ayasofya Hürrem Sultan Hammam which was built by Mimar Sinan on behalf of Haseki Hürrem Sultan, the wife of Kanuni Sultan Suleyman; they explained that with its impressive architectural structure and historical texture, it is one of the monumental works of Istanbul and one of the places frequented by domestic and foreign tourists. When this situation is combined with the original service concept; It means that the bathhouse has a strong brand image. It is indicating that the bathhouse is not only used for hygiene purposes, but also has an important place in social life.

Research Article - This article was checked by iThenticate 
In addition to the Turkish baths which maintain their existence because of their utilization, as in the samples above, and contribute to the preservation of the tangible and intangible cultural heritage, the transformation of Turkish baths into museums can be a solution to their preservation in the context of tangible cultural heritage.

Museums are very important institutions in terms of reflecting the cultural accumulation of societies, protecting past values and promoting national culture. Museums are such a dominant feature of our cultural landscape that they frame our most basic assumptions about the past and about ourselves. People who might not ordinarily think much about museums may find themselves engaged in debate if an institution's decisions challenge their value systems (Marstine, 2006).

As keepers of the collective memory, museums can play a valuable role in providing an understanding of identity and in fostering a sense of belonging to a place or community for their users. In the face of immense and often painful political and cultural change in many countries, their museums can provide a valuable sense of connection between the past and the present and serve as a springboard for the future (Black, 2005).

As a cultural phenomenon, museums have a long history. Perceptions of their role and value have changed through time as the political and cultural values around them have themselves altered and developed. Today, museums can play a strong role in the social, cultural and economic life and wellbeing of a country in urban and rural settings. Both individually and collectively, museums can provide many benefits. Identifying and articulating those benefits within a clear policy framework helps to build the case-for-support for museums at all levels (Ambrose \& Paine, 2006).

These institutions are divided into various classes according to the contents of their collections and their characteristics (Özel,2016:179). One of the roles of museums in today's information societies is to help the cultural awareness of the society. Because museums make it easy to understand the cultural diversity of the society. Societies learn their unique traditions by seeing them in museums, thus transferring them from generation to generation. Bath museums can be given as an example.

The first Turkish Bath Museum of Turkey was established in 2012 in Beypazarı with the "Applied Bath Museum for a Sustainable Tourism Project", supported by Ankara Development Agency (Demir, 2013). Rüstem Pasha Bathhouse, one of the 32 bathhouses constructed by the order of Rüstem Pasha, son in law and the vizier of Suleyman the Magnificent in $16^{\text {th }}$ century is now the Beypazar1 Turkish Bath Museum (Figure 11 and 12).

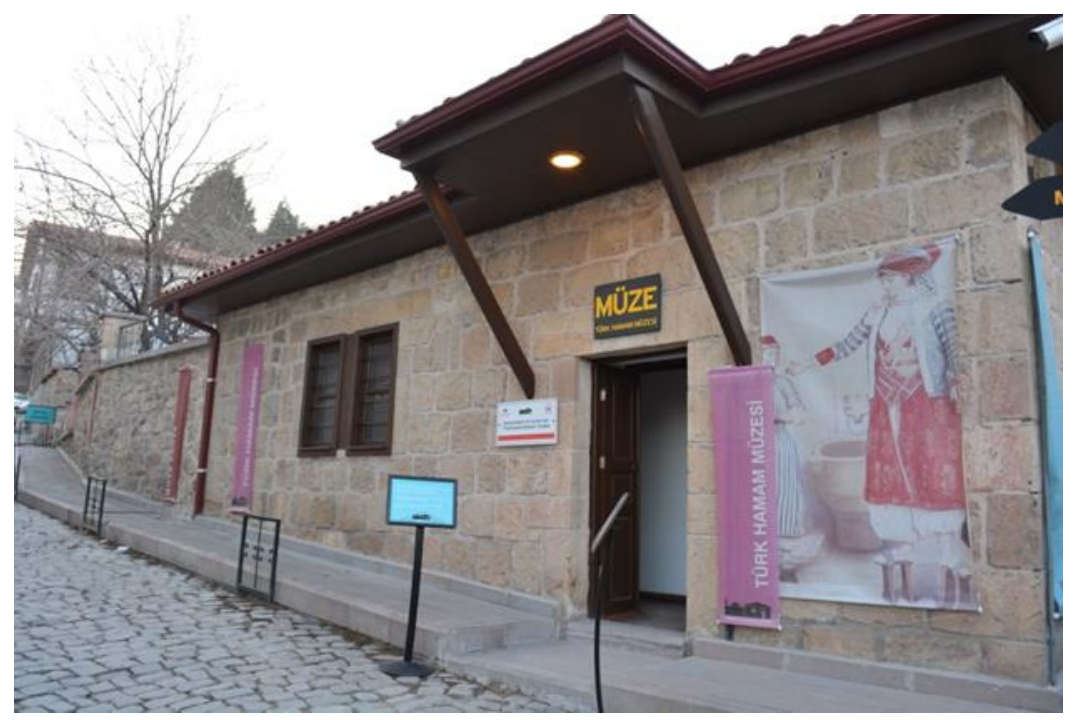

Research Article - This article was checked by iThenticate

Copyright $($ T The Turkish Online Journal of Design, Art and Communication 
The Turkish Online Journal of Design, Art and Communication - TOJDAC

ISSN: 2146-5193, January 2021 Volume 11 Issue 1, p.1-19

Figure 11. Beypazar1 Turkish Bath Museum (Anonymous, 2016e).

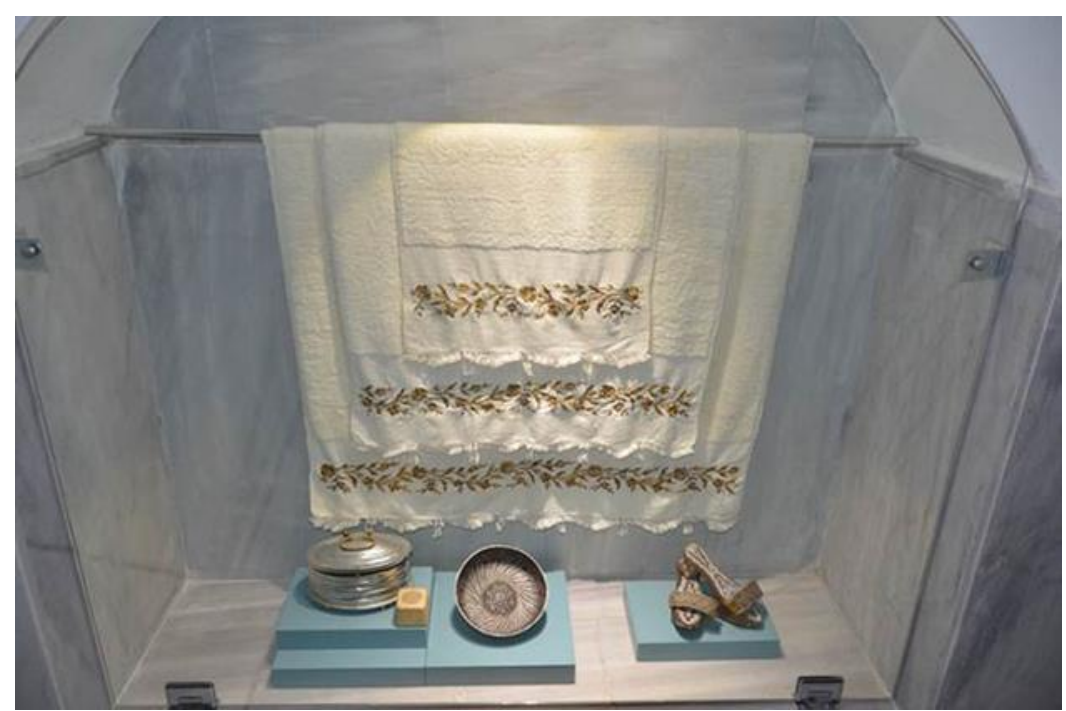

Figure 12. Interior View of the Beypazar1 Turkish Bath Museum (Anonymous, 2016f).

Bayezid II Bathhouses, one of the $16^{\text {th }}$ century Ottoman bathhouses in İstanbul was included into the World Cultural Heritage List by UNESCO in 1985 and was registered as a private museum under the name Bayezid II Turkish Bath Culture Museum in 2015. In the museum belonging to the İstanbul University, ethnographic artifacts belonging to the Turkish bath tradition are exhibited in display cabinets (Anonymous, 2016g) (Figure 13 and Figure 14).

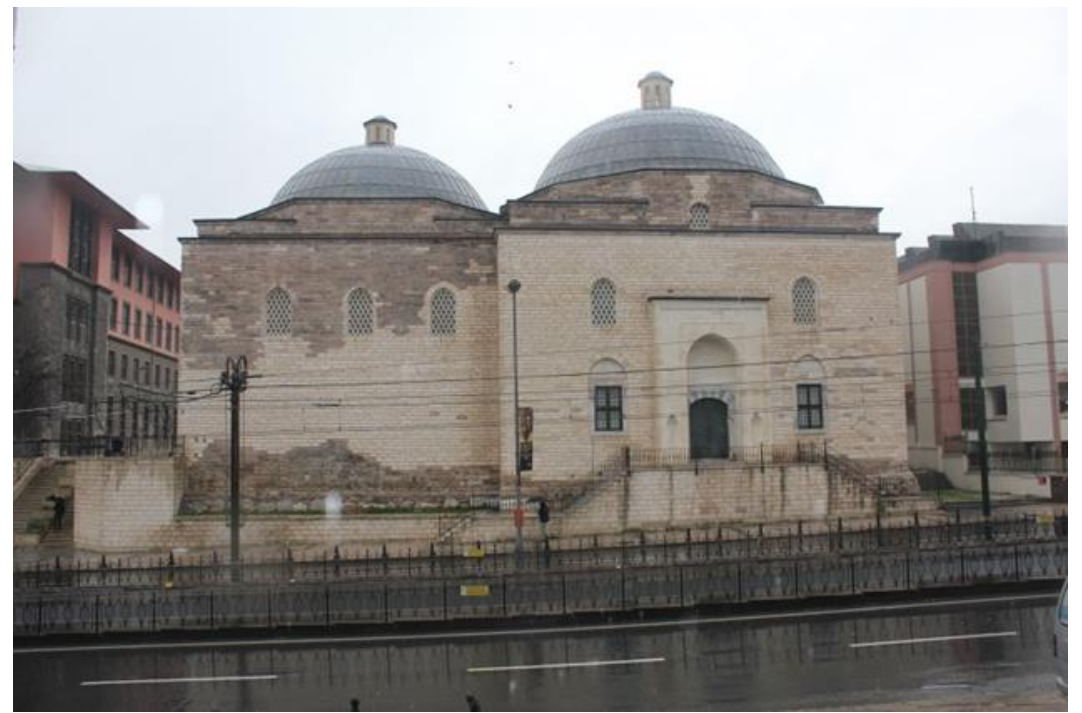

Figure 13. Bayezid II Turkish Bath (Hammam) Culture Museum (Anonymous, 2016g). 


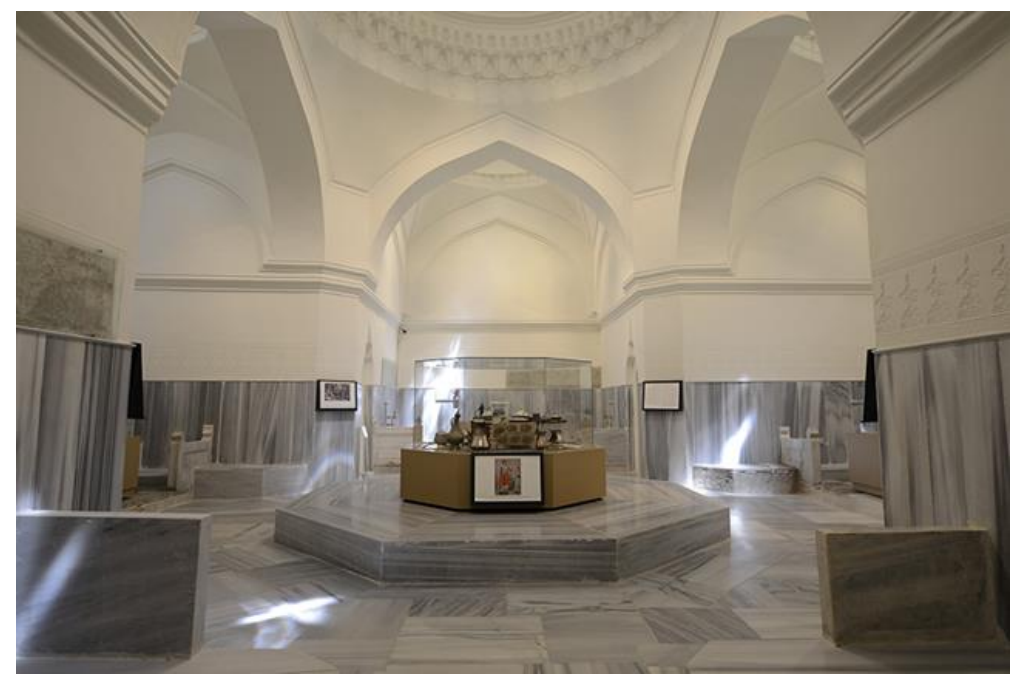

Figure 14. Interior View of the Bayezid II Turkish Bath (Hammam) Culture Museum (Anonymous, 2016h).

Another bath (hammam) museum is the Gaziantep Bath Museum. The building, which has served as the Pasha Hammam for many years, was completed by the Gaziantep Metropolitan Municipality in 2015 and transformed into a museum where Gaziantep bath culture is kept alive.

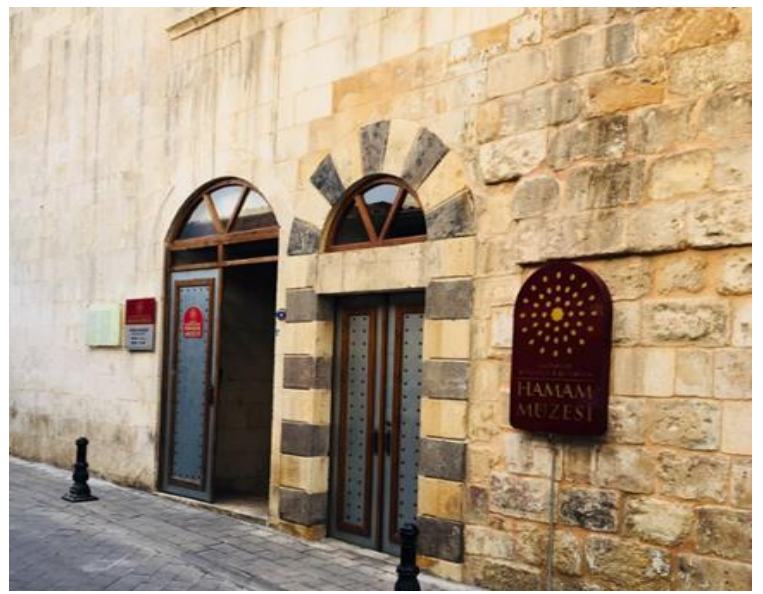

Figure 15. Gaziantep Bath (Hammam) Museum, (Yanar's photo archive, 2020)

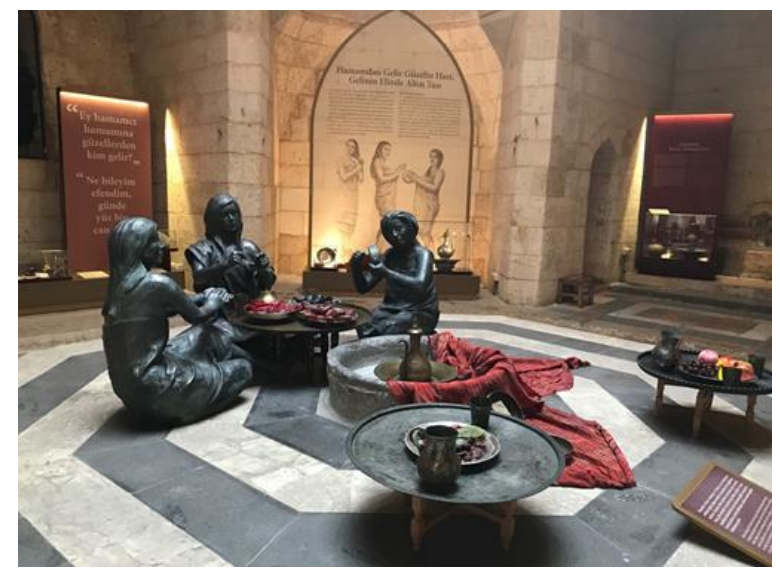

Figure 16. Interior View of the Gaziantep Bath (Hammam) Museum, (Yanar's photo archive, 2020)

Research Article - This article was checked by iThenticate 
Transforming Turkish baths into museums is a job that requires expertise in both bath culture and architecture. Bath Museums are established to compile, preserve, research and exhibit the bath and cleaning culture and to convey this cultural accumulation to the audience. Bath museums are shaped to bring together the material culture, objects and traditions of the past related to the bath culture. Bath museums are important in terms of bringing historical Turkish baths to cultural tourism.

\section{CONCLUSION}

Since the beginning of civilizations, body cleaning has been beneficial in the cultural, social and economic development and progress of societies and has formed the concept of bath culture. It is known that in the history of civilization, water areas were given great importance and were built in many buildings. It is thought that the special protection of historical baths that continue to exist is of great importance in terms of transferring the Turkish bath culture to future generations in all aspects.

Studies about Turkish baths primarily focused on architecture and art history aspects of the subject. This study was carried out with the purpose to state that, the conservation of the Turkish bath as a part of cultural heritage requires a holistic approach towards the conservation of both tangible and intangible cultural heritage, to emphasize that the approaches developed towards the conservation and sustainment of culture while taking tangible and intangible cultural heritage into account separately will be lacking and with the purpose of evaluating the spatial, functional and traditional aspects of the subject. Another important topic in the study is the detailed analyses of the traditional objects used in Turkish baths.

It is certain that the impact and importance of baths, which were irreplaceable parts of the Ottoman architecture and social life, are not as prominent today as they were in the past. Despite it lost its vitality, the fact that this tradition continues to exist in İstanbul and in some cities of Anatolia is very important due to the fact that the Turkish bath is "the symbol of a living culture that is passed down through generations". It is necessary to make an effort to sustain traditional Turkish baths, which have historical significances, as functional places. Intangible cultural heritage changes or even transforms depending on the people or contexts that keep it alive. Turkish baths, which have an important place among alternative touristic products due to the fact that they have been interesting and reflective of the traditional Turkish culture throughout history, provides a very special experience for tourists. Bathing and cleaning together with strangers in Turkish baths are accepted as a part of the traditional ritual. It is theorized that the existence of Turkish customers with bathhouse habits is very important to keep Turkish bath tradition alive and to transfer it. Also, in order to keep intangible cultural heritage alive, people who carry it are needed. Therefore, the interest and the sensitivity of the people who may transfer the tradition to keep it alive are needed.

In addition to the historical bathhouses which are very important as parts of cultural heritage, finding a solution to transform presently disused bathhouses that exist in every region of Anatolia into functional places may be an important step to keep the culture alive that. In case bathhouses cannot be transformed into functional places, another solution may be to turn them into museums to conserve the local and traditional properties. Anatolia is very rich in objects used in Turkish baths. The fact that the Turkish bath objects can also be used in daily life is very important in terms of sustainability. Transferring these objects to daily life with contributions of collectors to this process and exhibitions of quality examples will help prevent the degeneration regarding these objects.

As a museum type a Turkish bath museum is a kind of tiny museum with small scale but huge and deep background of every's life archaeology and folk culture. These microcosmos of folk culture and heritage museums offer a great variety of aspects of the native culture. One of the easiest ways to experience traditional culture is by exploring folk-based museums including ethnographical collections, old family mansions, village museums, special folk museums as bath museum etc. These museums make audiences wander around traditional buildings, ways of life, traditions, old shops, and more. The buildings are

Research Article - This article was checked by iThenticate 
furnished with original pieces and feature locals dressed in costumes weaving tales about life back in the day. In these museums generally it is possible watching craftspeople at work. This approach makes the museology more alive and inclusive. Their goal is to teach traditional lifestyles and preserve a country's heritage. Some bath museums have taken on contemporary and inclusive challenges in different ways. In general, they are willing to address the questions of whose history is being constructed and whose memories are being negotiated by them.

The spatial, functional and traditional structures of Turkish baths, traditional usage of bath objects and bath museums, are research topics that need to be studied in detail. For this reason, this study has a guiding nature for future studies.

\section{REFERENCES}

Ambrose, T.; Paine, C. (2006). Museum Basics. 2nd ed. UK: Routledge.

Anonymous. (2016). Retrieved from: http://www.berksav.org/berksav\&turkislameserleri2.asp

Anonymous. (2016a). Retrieved from: http://www.sehirlersavasi.com/ilce-

resimleri/index.asp?resimid $=3038 \&$ ilce $=11 \& \mathrm{il}=1$

Anonymous. (2016b). Retrieved from: http://www.e-yalova.com/il\%C3\%A7eler/termal.html

Anonymous. (2016c). Retrieved from: http://www.ekrembugraekinci.com/makale.asp?id=533

Anonymous. (2016d). Retrieved from: http://www.constantinople-historical-fine-arts-

emporium.com/index.php/galleries/gallery-1

Anonymous. (2016e). Retrieved from: http://www.yoldakitosbaga.files.wordpress.com

Anonymous. (2016f). Retrieved from: http://www.beypazari.bel.tr/rehber-8-hamam-muzesi.html

Anonymous. (2016g). Retrieved from: http://muzeyum.istanbul.edu.tr/?page_id=6591

Anonymous. (2016h). Retrieved from: http://iutercih.istanbul.edu.tr/index.php/author/s-turkoglu/

Anonymous, (1997). Ayna. Eczacıbaşı Sanat Ansiklopedisi. 1. Cilt. Yapı Endüstri Merkezi Yayınları Hürriyet Ofset, s.178

Anonymous (2019a). Buhurdan, Gülabdan. Büyük Türkçe Sözlük. www.sozluk.gov.tr Erişim tarihi: $06 / 08 / 2019$

Anonymous (2019b). Sabunluk. Türkiye Türkçesi Ağızları Sözlüğü. www.sozluk.gov.tr Erişim tarihi: $06 / 08 / 2019$

Anonymous (2019c). Mühür, Peşkir. Güncel Türkçe Sözlük. www.sozluk.gov.tr Erişim tarihi: 05/09/2019

Anonymous (2020). Cağaloğlu Hamamı. https://islamansiklopedisi.org.tr/cagaloglu-hamami Erişim tarihi: $10 / 12 / 2020$

Arlı, M. (1990). Köy El Sanatları. Ankara Üniversitesi Ziraat Fakültesi Yayınları:1185. Ders kitabı: 339. Ankara Üniversitesi Ziraat Fakültesi Baskı Ofset Ünitesi, Ankara, 76s.

Arseven, C.E. (1950a). Mühür. Sanat Ansiklopedisi. Cilt III, XIV. Fasikül, Milli Eğitim Basımevi, İstanbul, s.1481.

Arseven, C.E.(1950b.) Nalın. Sanat Ansiklopedisi. Cilt III. XIV. Fasikül, Milli Eğitim Basımevi, İstanbul, s.1498.

Arseven, C.E. (1952). Tarak. Sanat Ansiklopedisi. Cilt IV. Milli Eğitim Bakanlığı. Milli Eğitim Basımevi, İstanbul, 1912-1913.

Arseven, C.E.(1958). Ayna. Sanat Ansiklopedisi. Maarif Basımevi. Cilt 1. s.142. 
Atalayer, G. (1980). Buldan dokumaları. Devlet Tatbiki Güzel Sanatlar Yüksekokulu. Sanatta Yeterlik Tezi, İstanbul. 180s.

Basat, E. M. (2013). Somut ve Somut Olmayan Kültürel Mirası Birlikten Koruyabilmek. Milli Folklor, 61-71.

Black, G. (2005). The Engaging Museum: Developing Museums for Visitor Involvement. UK: Routledge.

Bozok, D. (2005). Türk Hamamı ve Geleneklerinin Turizmde Uygulanışı: Bursa Merkez İlçede Bir Araştırma. Balıkesir Sosyal Bilimler Dergisi, 62-86.

Büyüktanır, F. (2009). Geçmişten Günümüze Sivas'ta Hamam Kültürü̈. Cumhuriyet Üniversitesi Sosyal Bilimler Enstitüsü Türk Dili ve Edebiyatı Anabilim Dalı, Halk Bilimi (Folklor) Bilim Dalı Yüksek Lisans Tezi. Sivas.

Davulcu, M. (2020). Antalya-Elmalı'da Hamam Kültürü ve "Bey Hamamı" Folklor Akademi Dergisi. Cilt:3, Say1: 1, 185-210.

Demir, S. (2013). Türk Hamam Müzesi ve Kına Hamamı Sergisi. Ankara Araştırmaları Dergisi, 48-55.

Elmasoğlu,K.,Ertürk,H. (2019). Marka Ritüellerinin Marka Imajına Yansımaları: Ayasofya Hürrem Sultan Hamamı. Gümüşhane University e-journal of Faculty of Communication. vol.1,number 1. p;205-238.

Emiroğlu, İ. (2010). Konya'da Hamam Kültürü ve Kullanım Eşyaları. Selçuk Üniversitesi Sosyal Bilimler Enstitüsü Sanat Tarihi Anabilim Dalı Yüksek Lisans Tezi. Konya

Erdoğdu, A. (2000). Osmanlı mutfağında kullanılan sofra gereçleri. Hünkar Beğendi: 700 Yıllık Mutfak Kültürü̈. Çevik, Nihal Kadığlu (yayına hazırlayan). Kültür Bakanlığı Yayınları: 2348, Halk Kültürlerini Araştırma ve Geliştirme Genel Müdürlüğü Yayınları: 290. Maddi Kültür Dizisi:24. TŞOF Plaka Matbaac1lık, II Bask1. 61-74.

Gaziantep Turkish Bath. (Gaziantep Hamam Müzesi).

http://www.gaziantepturizm.gov.tr/TR,174063/gaziantep-hamam-muzesi.html . Erişim Tarihi. 22.09.2020.

Ito, N. (2003). IntangibleCultural Heritage Involved in TangibleCultural Heritage. Retrieved from: http://www.international.icomos.org/victoriafalls2003/ papers /A3-2\%20-\%Ito.pdf >.

Koçu, R.E. (1969). Peştamal. Türk Giyim Kuşam ve Süslenme Sözlüğü. Sümerbank Kültür Yayınları, $255 \mathrm{~s}$.

Kuruçay, A. (2011). İstanbul'un 100 Hamamı. İstanbul: İBB Kültür A.Ş. yayınları.

Marstine, J. (2006). New Museum Theory and Practice. UK: Blackwell Publishing.

Ortaç, H.S. (1994). Kadife ve havlu dokuma teknikleri, geleneksel ürünlerinin özellikleri ve özgün çalışmalar. Gazi Üniversitesi Sosyal Bilimler Enstitüsü Doktora tezi (yayımlanmamış), 236s.

Önge, Y. (1988). Mimarbaşı Koca Sinan'ın Yaşadı̆̆ı Çağ ve Eserleri. iS: T.C. Başbakanlık Vakıflar Genel Müdürlüğü.

Özel,N.(2016). Müzelerde Bilginin Düzenlenmesi ve Erişime Sunulması: Ankara'daki Müzelere Yönelik Bir Araştırma. DTCF Dergisi 56.1: 177-209.

Özgen, Ö. (2016). Kültürel Miras Kapsamında “Türk Hamamı” Üzerine Bir İnceleme. İletişim Kuram ve Araştırma Dergisi, 42,11-138.

Renda, G. (2012). Ressam Gözüyle Osmanlı Hamamı. N. Ergin içinde, Anadolu Medeniyetlerinde Hamam Kültürü: Mimari, Tarih ve Imgelem (s. 369-403). İstanbul: Koç Üniversitesi Yayınları. 
Tofaş Sanat Galerisi (2009). Eski Hamam Eski Tas. İstanbul: Yapı Kredi Yayınları: 3007, Mas Matbaacilik.

Türkan, K. (2009). Türk Masallarında Mimari: Hamam ve Işslevleri. Milli Folklor, 162-174.

Türkoğlu, S. 1995. Maden sanatı ve kuyumculuk. Geleneksel Türk Sanatları (hazırlayan: Özel, M.). Kültür Bakanlığı. Cem Ofset, İstanbul, 13-41.

Uluumay, E. (2009). Hamam Kültürü Üzerine, Eski Hamam Eski Tas. iSTANBUL: Tofaş Sanat Galerisi Yayınları: 1, Yapı Kredi Yayınları: 3007, Mas Matbaacılık.

Unesco. (2004). Yamato Declaration on Integrated Approaches for Safeguarding Tangible and Intangible Cultural Heritage International Conference on The Safe Guarding of Tangible and Intangible Heritage Organized by the Japanese Agency for Cultural Affairs and UNESCO. Japan.

Yaman, T. (2010). Türk Hamamının Mekansal Kurgusu “ İstanbul Hamamları. Mimar Sinan Güzel Sanatlar Üniversitesi Fen Bilimleri Enstitüsü. İç Mimarlık Anabilim / Anasanat Dalı. Yüksek Lisans Tezi. İstanbul.

Yegül, F. K. (2009). Anadolu Su Kültürü: Türk Hamamlarl ve Yıkanma Geleneğinin Kökleri ve Geleceği. Anatolia, 99-118.

Yegül, F. K. (2012). “Anadolu Hamam Kültürü: Bin Işılk Huzmesi, Bin Ilık Parmak”, Anadolu Medeniyetlerinde Hamam Kültürü: Mimari, Tarih ve İmgelem. İstanbul: Koç Üniversitesi Yayınları, 16-66.

Yılmazkaya, O. (2002). Aydınlık Kubbenin Altındaki Sıcaklık Türk Hamamı. İstnabul: Çitlembik. 